\title{
Mechanical and Durability Properties of Concrete Incorporating Flyash
}

\author{
P. Mugilvani, Anish C, Thendral. S
}

Abstract: India is a second largest producer of cement in the world. about 300 million tones of cement had produced in 2012. Day to day life we using large amount of cement it causes to reduction of natural resources. By using coal $60 \%$ of electricity was produced per annum. fly ash are produced as by product in coal about 175 million tones. so as we trying to replace cement by using admixture fly ash.

As per indian government norms that at least $10 \%$ of fly ash should be used during cement production.fly ash has zero percentage of binding property so we replacing the cement by fly ash up to $70 \%$ only and our motive are how the mechanical and durability properties perform in the concrete due to the replacing large amount of fly ash. we find that fly ash reduced chloride attacking in concrete, reducing the pores size, improved workability.

Hence, higher volumes of fly ash can be used to replacecement in concrete mixes and care should be taken during the design mix to obtain the similar compressive strengths as that of the control mix. this can be achieved by reducing the water cement ratios of concrete mixes incorporated with higher volumes of fly ash.

Keywords - Electricity, Fly ash, Compressive Strength

\section{INTRODUCTION}

Coal is the result of a large number of long periods of deteriorating vegetable issue under strain, and its substance arrangement is inconsistent. What's more, electric organizations advance power creation from coal utilizing added substances, for example, pipe gas conditioners, sodium sulfate, oil, and different added substances to control consumption, outflows, and fouling[1]-[6]. The subsequent fly debris can have a variable organization and contain a few added substances just as items from inadequate burning.

\section{RESULTS AND DISCUSSION}

\section{A. Experimental Setup}

Solid compressive quality prerequisite can fluctuate from $17 \mathrm{Mpa}$ for private cement to $28 \mathrm{Mpa}$ and higher business structure. High quality upto and surpassing 70Mpa are determined for specific applications[7]-[12].

Revised Manuscript Received on October 22, 2019

P. Mugilvani, Department of Civil Engineering, Bharath Institute of Higher Education and Research, Chennai , India. Email: mugilvanipalanivel@gmail.com

Anish C, Department of Civil Engineering, Bharath Institute of Higher Education and Research, Chennai , India. Email: anishdavidpaul@gmail.com

Thendral. S, Department of Civil Engineering, Bharath Institute of Higher Education and Research, Chennai , India. Email: thendral.cs@gmail.com

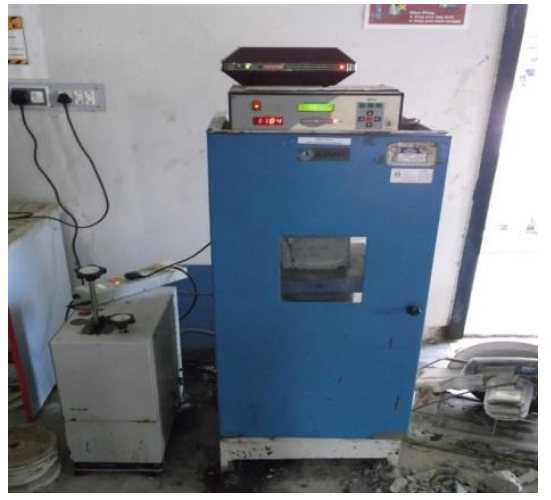

Figure:1 Compression Testing Machine with Specimen

\begin{tabular}{|c|c|c|c|c|c|c|c|}
\hline \multirow[t]{2}{*}{ S.Ne. } & \multirow[t]{2}{*}{$\begin{array}{l}\text { Cube } \\
\text { Size }\end{array}$} & $7 d$ & $28 \mathrm{~d}$ & $56 \mathrm{~d}$ & $7 d$ & $28 \mathrm{~d}$ & $56 \mathrm{~d}$ \\
\hline & & \multicolumn{3}{|c|}{ Load } & \multicolumn{3}{|c|}{$\begin{array}{l}\text { Compressive } \\
\text { Strength }\end{array}$} \\
\hline & $0-100$ & & & & & & \\
\hline 1 & 22500 & 711.1 & 1285.9 & 1317.9 & 31.6 & 57.2 & 58.6 \\
\hline 2 & 22500 & 704 & 1169.4 & 1301.5 & 31.3 & 52.0 & 57.8 \\
\hline \multirow[t]{2}{*}{3} & 22500 & 755.4 & 1216.5 & 1306.3 & 33.6 & 54.1 & 58.1 \\
\hline & $20-80$ & & & & & & \\
\hline 1 & 22500 & 684.0 & 1112.0 & 1184.6 & 30.4 & 49.4 & 52.6 \\
\hline 2 & 22500 & 676.6 & 999.1 & 1204.1 & 30.1 & 44.4 & 53.5 \\
\hline \multirow[t]{2}{*}{3} & 22500 & 674.1 & 951.7 & 1211.1 & 30.0 & 42.3 & 53.8 \\
\hline & $30-70$ & & & & & & \\
\hline 1 & 22500 & 477.7 & 793.9 & 1041.4 & 21.2 & 35.3 & 46.3 \\
\hline 2 & 22500 & 462.2 & 855.8 & 1063.7 & 20.5 & 38.0 & 47.3 \\
\hline \multirow[t]{2}{*}{3} & 22500 & 431.2 & 768.2 & 1014.0 & 19.2 & 34.1 & 45.1 \\
\hline & $50-50$ & & & & & & \\
\hline 1 & 22500 & 273.7 & 426.3 & 647.3 & 12.2 & 18.9 & 28.8 \\
\hline 2 & 22500 & 301.7 & 481.7 & 599.3 & 13.4 & 21.4 & 26.6 \\
\hline \multirow[t]{2}{*}{3} & 22500 & 305.6 & 504.3 & 588.9 & \begin{tabular}{|l|}
13.6 \\
\end{tabular} & 22.4 & 26.2 \\
\hline & $70-30$ & & & & & & \\
\hline 1 & 22500 & 148.2 & 303.2 & 462.2 & 6.6 & 13.5 & 20.5 \\
\hline 2 & 22500 & 152.7 & 313.3 & 442.1 & 6.8 & 13.9 & 19.6 \\
\hline \multirow[t]{2}{*}{3} & 22500 & 169.6 & 267.3 & 411.8 & 7.5 & 11.9 & 18.3 \\
\hline & $\begin{array}{l}70-30 \\
\mathrm{~W} / \mathrm{C} \\
\end{array}$ & & & & & & \\
\hline 1 & 22500 & 186.3 & 329.4 & 502.7 & 8.3 & 14.6 & 22.3 \\
\hline 2 & 22500 & 174.4 & 369.8 & 484.7 & 7.8 & 16.4 & 21.5 \\
\hline 3 & 22500 & 178.6 & 344.9 & 550.0 & 7.9 & 15.3 & 24.4 \\
\hline
\end{tabular}

Table 1: compressive strength Test Result

\section{B. Flexural Strength}

Flexural quality is one proportion of the elasticity of cement. It is a proportion of an unreinforced solid pillar or section to oppose disappointment in twisting. It is estimated by stacking $6 \times 6$-inch $(150 \times 150 \mathrm{~mm})$ solid bars with

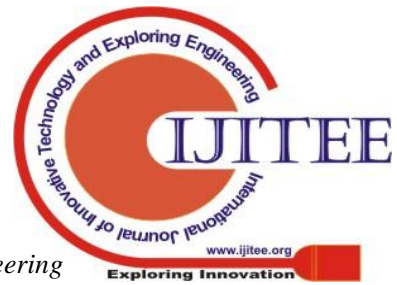


a range length at any rate multiple times the profundity. [13]-[17]. The flexural quality is communicated as modulus of crack (MR) in psi (MPa) and is controlled by standard test strategies ASTM C 78(third point stacking) or ASTM C 293 (focus point stacking).

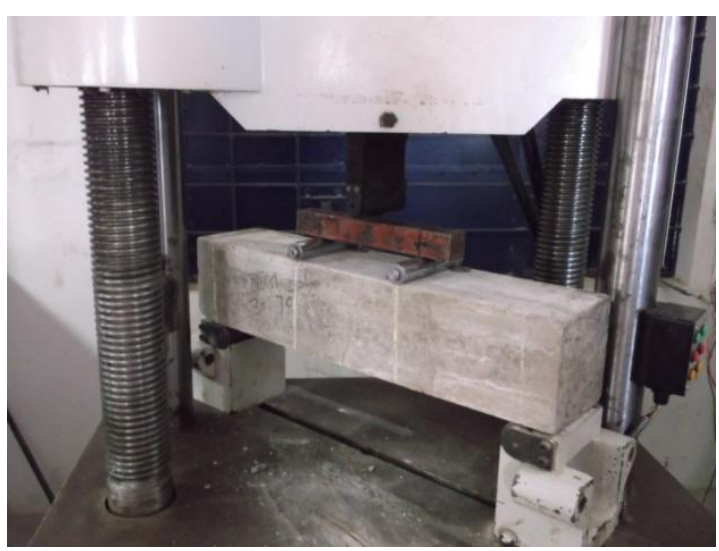

Fig 2: Flexural strength test of concrete

\begin{tabular}{|c|c|c|c|c|c|c|c|c|c|}
\hline S.No & $\begin{array}{l}\text { Concrete } \\
\text { Mix }\end{array}$ & \begin{tabular}{|l|} 
Grade of \\
Concrete \\
\end{tabular} & L & B & D & Load & $\mathrm{F}_{\mathrm{b}}$ & $\mathrm{Axg}$ & Rea \\
\hline 1 & \multirow{2}{*}{ Control } & \multirow{10}{*}{ M30 } & 700 & 150 & 150 & 32.32 & 5.75 & & \multirow{10}{*}{3.83} \\
\hline 2 & & & 700 & 150 & 150 & 32.55 & 5.79 & 2.17 & \\
\hline 3 & \multirow{2}{*}{$20 \%$} & & 700 & 150 & 150 & 31.05 & 5.52 & & \\
\hline 4 & & & 700 & 150 & 150 & 30.5 & 5.42 & 2.47 & \\
\hline 5 & \multirow{2}{*}{30} & & 700 & 150 & 150 & 29.6 & 5.26 & & \\
\hline 6 & & & 700 & 150 & 150 & 29.4 & 5.23 & 2.24 & \\
\hline 7 & \multirow{2}{*}{$50 \%$} & & 700 & 150 & 150 & 13.25 & 2.36 & & \\
\hline 8 & & & 700 & 150 & 150 & 12.96 & 2.30 & 2.33 & \\
\hline 9 & \multirow[b]{2}{*}{$70 \%$} & & 700 & 150 & 150 & 12.45 & 2.21 & \multirow[b]{2}{*}{2.19} & \\
\hline 10 & & & 700 & 150 & 150 & 12.24 & 2.18 & & \\
\hline
\end{tabular}

Table 2: Flextural Strength Result

\section{Durability properties}

\section{Rapid Chloride Penetration Test}

This strategy comprises of checking the measure of electrical flow went through 2 in. (51-mm) thick cuts of 4 in. (102-mm) ostensible measurement centers or chamber during a 6-h period. A potential distinction of $60 \mathrm{~V} \mathrm{dc}$ is kept up over the parts of the bargains. One of which is submerged in a sodium chloride arrangement, the other in a sodium hydroxide arrangement[18]-[22]. The absolute charge went, in coulombs, has been seen as identified with the safe of the example to chloride particle entrance.

\begin{tabular}{|c|c|}
\hline Charge passed(coulombs) & Chloride ion penetrability \\
\hline$>4000$ & High \\
\hline $2000-4000$ & Moderate \\
\hline $1000-2000$ & Low \\
\hline $100-1000$ & Very low \\
\hline$<100$ & Negligible \\
\hline
\end{tabular}

Table 3: Chloride Ion Penetrability Based on Charge Passed

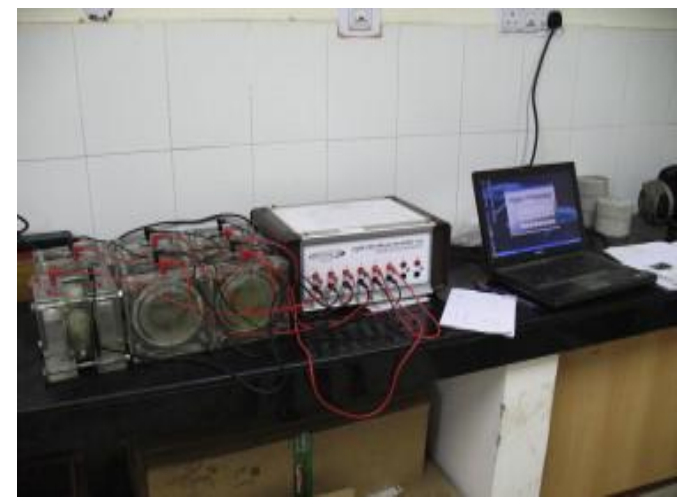

Fig 3: Rapid chloride penetration test

\section{CONCLUSION}

1. The after are the deductions drawn dependent on the examinations directed on the control just as concrete blends in with various levels of substitution of fly debris

2. The control blend and the solid blend in with $20 \%$ substitution level of fly debris fulfill the objective quality for M30 grade at 28 years old days. The solid blends fused in with $35 \%, 50 \%$ and $70 \%$ fly debris don't fulfill the objective quality criteria at 28 days[23]-[28].

3. The blend in with $35 \%$ substitution level of fly debris accomplishes the objective quality at 56 years old days, while the blends in with $50 \%$ and $70 \%$ substitution levels don't fulfill the criteria even at 56 years old days.

4. The flexural quality of control, $20 \%$ and $35 \%$ substitution levels of fly debris fulfill the criteria of $0.7 \sqrt{ }$ (fck) at 28 years old days, while the blends joining more elevated level of substitution of fly debris show lower esteems[29]-[34].

5. The introductory pace of retention in the sorptivity tests for the forcontrol,20\% and $35 \%$ are nearly the equivalent. In any case, for the blends in with higher volume of fly debris, the ingestion esteems are on the higher side, demonstrating that water bond proportions must be appropriately changed in accordance with get equal compressive qualities as that of the control concrete at 28 years old days.

6. There is a progressive increment in the optional retention on account of the blends in with 20 and $35 \%$ substitution levels of fly debris, while on account of the control blend, the auxiliary pace of ingestion increments abruptly showing that the expansion fly debris will have a huge improvement in the solidness qualities of cement blends.

\section{REFERENCES}

1. Iyappan L., Dayakar P., Identification of landslide prone zone for coonoortalukusing spatial technology, International Journal of Applied Engineering 
Research,V-9,I-22,PP-5724-5732,Y-2014

2. Kumar J., Sathish Kumar K., Dayakar P.,Effect of microsilica on high strength concrete, International Journal of Applied Engineering Research,V-9,I-22,PP-5427-5432,Y-2014.

3. Dayakar P., Vijay Ruthrapathi G., Prakesh J., Management of bio-medical waste, International Journal of Applied Engineering Research,V-9,I-22,PP-5518-5526,Y-2014

4. Swaminathan N., Dayakar P., Resource optimization in construction project, International Journal of Applied Engineering Research,V-9,I-22,PP-5546-5551,Y-2014

5. Venkat Raman K., Dayakar P., Raju K.V.B.,An experimental study on effect of cone diameters in penetration test on sandy soil, International Journal of Civil Engineering and Technology,V-8,I-8,PP-1581-1588,Y-2017.

6. Saritha B., Chockalingam M.P.,Photodradation of malachite green DYE using TIO2/activated carbon composite,International Journal of Civil Engineering and Technology,V-8,I-8,PP-156-163,Y-2017

7. Shendge R.B., Chockalingam M.P., Saritha B., Ambica A.,Swat modelling for sediment yield: A case study of Ujjani reservoir in Maharashtra, India,International Journal of Civil Engineering and Technology,V-9,I-1,PP-245-252,Y-2018

8. Chockalingam M.P., Balamurgan V.,Modernisation of an existing urban road-sector in Chennai, a case study report,International Journal of Civil Engineering and Technology,V-8,I-8,PP-1457-1467,Y-2017

9. Saritha B., Chockalingam M.P.,Adsorption study on removal of basic dye by modified coconut shell adsorbent, International Journal of Civil Engineering and Technology,V-8,I-8,PP-1370-1374,Y-2017

10. Saritha B., Chockalingam M.P.,Adsorptive removal of heavy metal chromium from aqueous medium using modified natural adsorbent,International Journal of Civil Engineering and Technology,V-8,I-8,PP-1382-1387,Y-2017

11. Chockalingam M.P., Palanivelraja S.,Retrospective analysis of a theoretical model used for forecasting future air quality near the north Chennai thermal power plant,International Journal of Civil Engineering and Technology,V-8,I-8,PP-1457-1467,Y-2017

12. Saritha B., Chockalingam M.P.,Photodegradation of methylene blue dye in aqueous medium by $\mathrm{Fe}-\mathrm{AC} / \mathrm{TiO} 2$ Composite,Nature Environment Technology,V-17,I-4,PP-1259-1265,Y-2018

13. Shendge R.B., Chockalingam M.P., Kaviya B., Ambica A.,Estimates of potential evapotranspiration rates by three methods in upper Bhima Basin, In Maharashtra, India,International Journal of Civil Engineering and Technology,V-9,I-2,PP-475-480,Y-2018

14. Shendge R.B., Chockalingam M.P.,The soil and water assessment tool for Ujjani Reservoir,International Journal of Mechanical Engineering and Technology,V-9,I-2,PP-354-359,Y-2018

15. Shendge R.B., Chockalingam M.P.,A review on soil and water assessment tool,International Journal of Mechanical Engineering and Technology,V-9,I-2,PP-347-353,Y-2018

16. Sachithanandam P., Meikandaan T.P., Srividya T.,Steel framed multi storey residential building analysis and design,International Journa of Applied Engineering Research,V-9,I-22,PP-5527-5529,Y-2014

17. Meikandaan T.P., Ramachandra Murthy A.,Study of damaged RC beams repaired by bonding of CFRP laminates,International Journal of Civil Engineering and Technology,V-8,I-2,PP-470-486,Y-2017

18. Meikandaan T.P., Ramachandra Murthy A.,Retrofittng of reinforced concrete beams using GFRP overlays,International Journal of Civil Engineering and Technology,V-8,I-2,PP-423-439,Y-2017

19. Meikandaan T.P., Ramachandra Murthy A.,Flexural behaviour of RC beam wrapped with GFRP sheets,International Journal of Civil Engineering and Technology,V-8,I-2,PP-452-469,Y-2017

20. Meikandaan T.P., Murthy A.R.,Experimental study on strengthening of rc beams using glass Fiber,International Journal of Civil Engineering and Technology,V-9,I-11,PP-959-965,Y-2018

21. Meikandaan T.P., Hemapriya M.,Use of glass FRP sheets as external flexural reinforcement in RCC Beam,International Journal of Civil Engineering and Technology,V-8,I-8,PP-1485-1501,Y-2017

22. Saraswathy R., Saritha B.,Planning of integrated satellite township at Thirumazhisai,International Journal of Applied Engineering Research,V-9,I-22,PP-5558-5560,Y-2014

23. Saritha B., Ilayaraja K., Eqyaabal Z.,Geo textiles and geo synthetics for soil reinforcement,International Journal of Applied Engineering Research,V-9,I-22,PP-5533-5536,Y-2014

24. Ambica A., Saritha B., Changring G., Singh N B., Rajen M., Salman Md.,Analysis of groundwater quality in and around Tambaram taluk,
Kancheepuram district,International Journal of Civil Engineering and Technology,V-8,I-8,PP-1362-1369,Y-2017

25. Arunya A., Sarayu K., Ramachandra Murthy A., Iyer N.R.,Enhancement of durability properties of bioconcrete incorporated with nano silica,International Journal of Civil Engineering and Technology,V-8,I-8,PP-1388-1394,Y-2017

26. Ilayaraja K., Krishnamurthy R.R., Jayaprakash M., Velmurugan P.M., Muthuraj S.,Characterization of the 26 December 2004 tsunami deposits in Andaman Islands (Bay of Bengal, India),Environmental Earth Sciences,V-66,I-8,PP-2459-2476,Y-2012

27. Ilayaraja K.,Morphometric parameters of micro watershed in Paravanar sub-basin, Cuddalore District,International Journal of Civil Engineering and Technology,V-8,I-8,PP-1444-1449,Y-2017

28. Ilayaraja K., Singh R.K., Rana N., Chauhan R., Sutradhar N.,Site suitability assessment for residential areas in south Chennai region using remote sensing and GIS techniques, International Journal of Civil Engineering and Technology,V-8,I-8,PP-1468-1475,Y-2017

29. Ilayaraja K., Reza W., Kumar V., Paul S., Chowdhary R.,Estimation of land surface temperature of Chennai metropolitan area using Landsat images,International Journal of Civil Engineering and Technology,V-8,I-8,PP-1450-1456,Y-2017

30. Chitra R.,Experimental study on beam using steel fiber and latex,International Journal of Civil Engineering and Technology,V-8,I-8,PP-1395-1403,Y-2017

31. Chitra R.,Analysis of traffic and management at Kovilambakkam intersection,International Journal of Civil Engineering and Technology,V-8,I-8,PP-1433-1443,Y-2017

32. Aswathy M.,Experimental study on light weight foamed concrete,International Journal of Civil Engineering and Technology,V-8,I-8,PP-1404-1412,Y-2017

33. Aswathy M.,Wastewater treatment using constructed wetland with water lettuce (Eichornia Crasipies),International Journal of Civil Engineering and Technology,V-8,I-8,PP-1413-1421,Y-2017

34. Kiruthiga K., Anandh K.S., Gunasekaran K, Assessment of influencing factors on improving effectiveness and productivity of construction engineers, 2015, International Journal of Applied Engineering Research, V - 10,I -17,p -13849-13854.

\section{AUTHORS PROFILE}

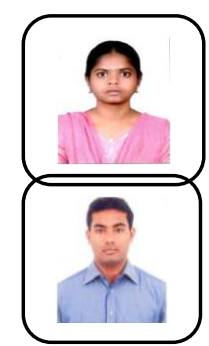

P. Mugilvani, Assistant Professor, Department of Civil Engineering, Bharath Institute of Higher Education and Research, Chennai, India.

Anish C , Assistant Professor, Department of Civil Engineering, Bharath Institute of Higher Education and Research, Chennai , India

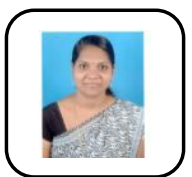

Thendral. S, Assistant Professor, Department of Civil Engineering, Bharath Institute of Higher Education and Research, Chennai, India. 